\title{
Sciendo
}

10.2478/topling-2020-0004

\section{A further argument for a syncretic analysis of DOM and dative in Spanish}

\author{
Carlos Muñoz Pérez* \\ Pontifical Catholic University of Chile, Chile
}

\begin{abstract}
This paper offers an argument to analyse the Spanish form /a/ as a syncretic case marker for accusative differential object marking (DOM) and dative. The literature on free relative clauses has established that syncretism allows the repair of feature mismatches arising from contradictory selectional requirements between the matrix and the embedded predicates. By combining clitic left dislocation constructions (CLLD) and free relatives, it is shown here that DOM and dative grant the same repairing effect in Spanish, so it follows that they must be syncretic categories. The same type of configuration distinguishes the directional preposition $a$ and the dative case marker, which is taken to indicate that these elements are mere homophones in the language. Furthermore, an analysis of the repairing effect of syncretism is offered.
\end{abstract}

\section{Key words}

free relatives, clitic left dislocation, differential object marking, dative, syncretism, Spanish

\section{Introduction}

The Spanish form /a/ appears in several syntactic contexts. It may introduce animate direct objects as in (1a), indirect objects as in (1b), and locative arguments as in (1c).

(1) a. Cosmo saludó [Do a Jeremías].

Cosmo saluted A Jeremías

'Cosmo saluted Jeremías.'

b. Jorge le compró una ensalada [ıo a Eliana]. Jorge DAT.3SG bought a salad A Eliana 'Jorge bought a salad to Eliana.'

c. Jorge fue $\quad[$ Loc a la playa $]$.

Jorge went A the beach

'Jorge went to the beach.'

The $a$-form heading the locative argument in (1c) is widely accepted to be a directional preposition with equivalent forms in many languages, e.g., English 'to', Japanese 'ni', Polish 'do'. Under the intuition that all $a$-forms in (1) pertain to a single natural class, the ones in (1a) and (1b) have also been traditionally analysed as prepositions. Thus, for instance, Alarcos Llorach (1994) takes indirect objects

\footnotetext{
* Address for correspondence: Carlos Muñoz Pérez, Catholic University of Chile, Faculty of Language and Literature, Av.Vicuña Mackenna 4860, Santiago, Chile, E-mail: carlos.munozperez@uc.cl
} 
in Spanish to be headed by the preposition $a$. In a similar way, Alcina Franch and Blecua (1975) describe the $a$-form in (1a) as a semantically empty preposition; in fact, the type of direct object in (1a) is usually referred to as complemento directo preposicional 'prepositional direct complement' (e.g., Pensado, 1995; Torrego, 1999).

However, there is now a long-standing consensus that the $a$-forms appearing in (1a) and (1b) are actually case markers. The $a$-form heading the direct object in (1a) is taken to be an accusative differential object marker (DOM), e.g., Brugè and Brugger (1996), López (2012), while the $a$-form in (1b) is assumed to be a dative case marker, e.g., Demonte (1995), Cuervo (2003), Pujalte (2012). This approach implies a categorial distinction between (1a) and (1b) on one side, and (1c) on the other: the former sentences contain nominal phrases (NPs), while the latter has a prepositional phrase (PP).

The fact that both DOM and dative are expressed by using the same exponent does not say anything about the reason why a single form manifests two distinct case values. A fairly standard implicit assumption involves considering the accusative and dative $a$-forms as mere diachronically related homophones. ${ }^{1}$ This is to say that there is no synchronic principle enforcing phonological identity between DOM and dative, i.e., it is a "synchronic coincidence" just like the homophony between banco 'bench' and banco 'bank': they are distinct vocabulary items that happen to be pronounced in the same way.

Assuming that the three $a$-forms in (1) illustrate a case of accidental homophony implies treating these elements as distinct grammatical objects. Therefore, separate spell-out rules need to be proposed for them. ${ }^{2}$
(2)
a. $\{\mathrm{ACC}\} \rightarrow / \mathrm{a} /$
b. $\{\mathrm{DAT}\} \rightarrow / \mathrm{a} /$
c. $\left\{\mathrm{P}_{\mathrm{DIR}}\right\} \rightarrow / \mathrm{a} /$

However, authors like Zdrojewski (2013) and Bárány (2018) defend the hypothesis that homophony between DOM and dative is not coincidental but motivated by synchronic principles, i.e., it is an instance of systematic syncretism. The basic intuition is that there are some syntactic contexts in which the accusative-dative distinction is irrelevant for the purposes of exponent selection, so both cases are spelled out by employing the same rule.
a. $\{\mathrm{ACC} / \mathrm{DAT}\} \rightarrow / \mathrm{a} /$
b. $\left\{\mathrm{P}_{\mathrm{DIR}}\right\} \rightarrow / \mathrm{a} /$

Bárány (2018) presents a number of reasons to support this approach. This paper aims to introduce a further argument for the syncretic treatment of DOM and dative in Spanish. The idea goes as follows: it has been observed that systematic syncretism allows the repair of feature-mismatches in free relatives in many languages (e.g., van Riemsdijk, 2006). In Spanish, the same repairing effect can be attested with DOM and dative, so it must be the case that these categories are syncretic.

The structure of the article is as follows: section 2 introduces the phenomenon of mismatch repair in free relatives via syncretism; section 3 presents the syntactic context in which an analogous effect can be attested in Spanish with DOM and dative; section 4 presents an analysis for the phenomenon. Finally, section 5 contains some conclusions.

\section{Case mismatching repair via syncretism}

Headed relative clauses typically modify a nominal constituent, namely the head of the relative.

\footnotetext{
${ }^{1}$ All Spanish $a$-forms in (1) seem to have their origin in the Latin directional construction ad+accusative. See discussion in Torrego (1999) for references.

${ }^{2}$ See López (2012) for a particular proposal of spell-out rules for DOM and dative along these lines.
} 
(4) I saw the person ${ }_{\text {head }}$ [ReL who you like].

On the contrary, free relative clauses are those lacking a head.

(5) I saw [ReL who you like].

A key distinction between these constructions is the number of functions performed by the wh-phrase in each case. In headed relative clauses as (4), the head of the relative is selected by the matrix predicate, while the wh-phrase is interpreted within the embedded clause. In free relatives, however, there is no head, so the wh-phrase must satisfy by itself the selectional requirements of both verbs. In (5), the two verbs subcategorize for the same type of argument (i.e., an NP), so a relative pronoun like who is able to serve as the object of both.

The scenario in which the selectional requirements of the verbs coincide is schematically illustrated in (6). The two verbs in the construction require a constituent of type $\alpha$. Since the wh-phrase satisfies this condition for both predicates, the resulting sentence is grammatical.

$$
\ldots \mathrm{V}_{\langle\alpha\rangle} \ldots\left[\text { REL wh-phrase } \alpha \ldots \mathrm{V}_{\langle\alpha\rangle}\right]
$$

Hypothetically, there could be cases in which the matrix and the embedded verbs require constituents with contradicting properties, e.g., one verb requires a constituent of type $\alpha$ while the other requires a constituent of type $\beta$. In this type of scenario there is a mismatch between the needs of both predicates so that a single wh-phrase cannot satisfy them at the same time. The resulting sentence is usually unacceptable.

$$
* \ldots \mathrm{V}_{\langle\alpha\rangle} \ldots\left[\text { REL wh-phrase } \alpha \ldots \mathrm{V}_{\langle\beta\rangle}\right]
$$

However, several scholars point out that this type of mismatch is resolved if the form of the whphrase is syncretic for the properties required by both predicates (e.g., van Riemsdijk, 2006; Citko, 2013; Himmelreich, 2017). That is, in a configuration where the matrix verb requires a constituent of type $\alpha$ and the embedded verb requires a constituent of type $\beta$, the resulting sentence is acceptable if $\alpha$ and $\beta$ are systematically expressed by the same exponent.

$$
\ldots \mathrm{V}_{\langle\alpha\rangle} \ldots\left[\text { ReL }_{\text {wh-phrase }} / \beta \ldots \mathrm{V}_{\langle\beta\rangle}\right]
$$

The three scenarios in (6), (7) and (8) have been extensively studied in languages in which relative pronouns manifest morphological case. Take as a first example the declination of personal and impersonal wh-pronouns in German. As the table in (9) shows, the forms in the impersonal paradigm are syncretic, so they are expected to repair case mismatches.

$\begin{array}{lr}\text { Personal } & \text { Impersonal } \\ \text { NOM wer } & \text { was } \\ \text { ACC wen } & \text { was } \\ \text { DAT wem } & - \\ \text { GEN wessen } & -\end{array}$

The German sentence in (10) illustrates the matching scenario that was previously sketched in (6). ${ }^{3}$ The verbs mag 'likes' and hasst 'hates' need an accusative complement; this requirement is satisfied for both verbs by the accusative wh-pronoun wen 'whom' heading the free relative.

(10) Hans mag ${ }_{(A C C)}\left[\right.$ wen $_{A C C}$ Maria hasst $\left._{(A C C)}\right]$. Hans likes who Maria hates

\footnotetext{
${ }^{3}$ Examples (10), (11) and (12) are taken from Himmelreich (2017).
} 
'Hans likes whoever Maria hates.'

The sentence in (11) illustrates a case mismatch in line with the abstract representation in (7). The matrix verb vertraut 'trusts' needs a dative argument, while the embedded verb mag 'likes' needs an accusative one. In this configuration, neither a dative nor an accusative wh-pronoun can appear in the construction. ${ }^{4}$
Hans vertraut $\{D A T\rangle$
Hans trusts
$\left[{ }^{*}\right.$ wem $_{D A T} /{ }^{*}$ wen $_{A C C}$
who
Maria $\left.\operatorname{mag}_{\{A C C}\right]$.
Maria likes
'Hans trusts whoever Maria likes.'

Unacceptability is avoided if the wh-phrase heading the free relative is syncretic for the case values required by the matrix and the embedded verb. As sketched in (8), the sentence in (12) has two verbs with conflicting needs: mag 'likes' requires an accusative phrase, and treibt 'drives' requires a nominative phrase. Since an impersonal pronoun is employed, and impersonal pronouns are syncretic in nominative and accusative (9), the case mismatch is repaired.
(12) Hans mag ${ }_{\langle A C C\rangle}$
[was wCC/NOM Maria $_{\text {zur }}$
Hans likes
what Maria to
$\begin{array}{ll}\text { Weißglut } & \left.\text { treibt }_{(\text {NOM) }}\right] . \\ \text { rage } & \text { drives }\end{array}$
'Hans likes whatever infuriates Maria.'

An analogous observation can be made on the basis of Polish data, another language that manifests morphological case on wh-pronouns. The table in (13) illustrates the declination of the pronoun ktokolwiek 'who'; notice that there is syncretism between the accusative and genitive forms.

\section{(13) NoM ktokolwiek \\ ACC kogokolwiek \\ DAT komukolwiek \\ GEN kogokolwiek}

Polish free relatives exhibit the same behaviour as their German counterparts: if the requirements of both the matrix and the embedded verbs match the wh-phrase, the sentence is acceptable. ${ }^{5}$
Jan pomaga $a_{(D A T)}$
[komukolwiek $k_{D A T}$
$\left.u f a_{[D A T\rangle}\right]$.
Jan help whomever
trusts
'Jan helps whomever he trusts.'

If the verbs require nominals with different case values, the free relative is deemed to be unacceptable, no matter the form of the wh-phrase heading it.
(15) Jan ufa $a_{(D A T\rangle}\left[*^{*}\right.$ komukolwiek $_{D A T} /$ kogokolwiek $_{A C C}$ wpuścil $l_{\{A C C\rangle}$ do domu]. Jan trusts whoever let to home

\footnotetext{
${ }^{4}$ I abstract away from certain mismatches that are tolerated in German: as Vogel (2001) points out, German allows case mismatches in free relatives as long as the case required by the embedded verb is lower in the case hierarchy (Blake, 1994) than the case required by the matrix verb.

i. Hans $\mathrm{mag}_{\{A C C\rangle}\left[\mathrm{wem}_{D A T} /{ }^{*}\right.$ wen $_{A C C}$ Maria vertraut $([\mathrm{DAT})]$. Hans likes who Maria trusts

'Hans likes whoever Maria trusts.'

This exception does not affect in any way the generalization that is exemplified in the main text, namely that systematic syncretism repairs mismatches. See Bergsma (2019) for a unified treatment of the full German pattern. ${ }^{5}$ The Polish examples in (14), (15) and (16) are also taken from Himmelreich (2017).
} 
'Jan trusts whoever he let into the house.'

This situation is resolved, however, if a syncretic wh-pronoun is able to satisfy the selectional needs of both verbs.

(16) Jan unika $a_{\langle G E N\rangle}\left[\right.$ kogokolwiek $_{G E N / A C C}$ wczoraj $_{\text {obrasit }}$ (ACC) $\left._{\text {J }}\right]$. Jan avoids whoever yesterday offended

'Jan avoids whoever yesterday offended.'

The German and Polish data unequivocally support the generalization that systematic case syncretism repairs case mismatches. This phenomenon can be further employed to diagnose other seemingly syncretic patterns in other languages. In particular, under the right conditions, it could be used to support a syncretic treatment of DOM and dative in Spanish.

\section{CLLD and free relatives in Spanish}

Relative pronouns do not exhibit inflectional case distinctions in Spanish. Free relatives in this language have been studied in terms of categorial mismatches, i.e., scenarios in which the matrix and embedded verbs require distinct types of constituents (e.g., Suñer, 1984). For instance, two verbs that require PP complements headed by the same preposition can form a free relative construction, e.g., (17a). A mismatch emerges if the verbs require distinct types of phrases, e.g., an NP and a PP as in (17b), or in case the verbs need different prepositions heading their complements, e.g., (17c).

$$
\begin{aligned}
& \text { a. ¿Te olvidaste }\{\text { de) }[P P \text { de quien] te enamoraste }\{d e\} \text { ? } \\
& \text { you forgot of who you fall.in.love } \\
& \text { 'Did you forget who you fell in love with?' }
\end{aligned}
$$

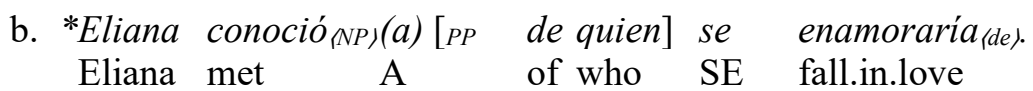

$$
\begin{aligned}
& \text { 'Eliana met who she would fall in love with.' } \\
& \text { c. *Jorge pensaba } a_{(e n\}} \text { en [PP de quien] se olvidó }\{d e \text {. } \\
& \text { Jorge thought in of who SE forgot } \\
& \text { 'Jorge thought about who he forgot.' }
\end{aligned}
$$

In order to test the hypothesis that DOM and dative are syncretic in Spanish, it is necessary to provide a configuration in which an element of the matrix clause unambiguously requires an accusative whphrase heading the relative, while an element in the embedded clause unambiguously requires a dative wh-phrase (or vice versa). It is contended here that Clitic Left Dislocation constructions (CLLD) may be employed to obtain such a configuration. As shown in (18), these constructions involve an NP argument in a dislocated position in the left periphery being doubled within the clause by a clitic.

$\begin{array}{rlllll}(18) & \text { a. }\left[\begin{array}{lll}\text { NP } & A & \text { Cosmo }\end{array},\right. & \text { lo } & \text { vi } & \text { hoy. } \\ \text { A } & \text { Cosmo } & \text { ACC.3SG.MASC } & \text { saw } & \text { today }\end{array}$

'Cosmo, I saw him today.'
b. $\left[\begin{array}{lll}N P & A & \text { Eliana }\end{array}\right]$ le A Eliana DAT.3SG
di un regalo.

'Eliana, I gave her a present'.

The CLLD construction has two properties that are relevant for the purposes of this paper. First, CLLD exhibits connectivity effects (Cinque, 1977), i.e., the features of the clitic must match those of the dislocated constituent. For example, the sentences in (19) show that a dislocated direct object like 
Cosmo (masculine and singular) cannot be doubled by a clitic with plural (19b), feminine (19c), or dative features $(19 \mathrm{~d}){ }^{6}$
a. $\left[\begin{array}{ccc}D O & A & \text { Cosmo }\end{array}\right]_{A C C}, \quad l o_{(A C C)}$ ACC.3SG.MASC saw
hoy. A Cosmo ACC.
smo, I saw him today.'
b. *[DO
A Cosmo $]_{S G}, \quad \operatorname{los}_{\{P L\rangle}$
A Cosmo ACC.3PL.MASC saw
hoy. today
c. $*\left[\begin{array}{lll}D O & A & \text { Cosmo }\end{array}\right]_{M A S C} l a_{\langle F E M\rangle}$ vi hoy.
A Cosmo ACC.3PL.FEM saw today
d. *[DO A A Cosmo DAT.3SG

$\begin{array}{ll}v i & \text { hoy. } \\ \text { saw } & \text { today }\end{array}$

In the same way, an indirect object such as Eliana (feminine and singular) in (20) cannot be doubled either by a plural (20b) or by an accusative clitic (20c).
a. $[I O$
A Eliana $]_{D A T}, \quad l e_{(D A T)}$ di un
regalo.
A Eliana
DAT.3SG
gave a
present

'Eliana, I gave her a present'.
b. *[IO
A Eliana $]_{S G}$,
A Eliana
$\operatorname{les}_{\langle P L\rangle}$
di un
regalo.
DAT.3PL
gave a
present
c. *[ı $\begin{aligned} \text { A Eliana } \\ \text { A Eliana }\end{aligned}$
$l a_{(A C C)}$
di un
regalo.
ACC.3SG
gave a
present

The second important property of CLLD is that wh-phrases (e.g. interrogative and relative pronouns) may participate in the construction and be doubled by a clitic (Jaeggli, 1982; Suñer, 1988; DobrovieSorin, 1990). There is, however, an asymmetry: while doubling an interrogative indirect object is the norm in most Spanish varieties (22), doubling of interrogative direct objects (21) is mostly forbiden and restricted to certain dialects: the phenomenon seems to be particularly productive in Limeño and has been widely attested in Rioplatense, although there is significant variation in the latter dialect, as some speakers tend to judge as unacceptable the relevant examples. ${ }^{7}$

\footnotetext{
are spelled out as datives; see Fernández-Ordóñez (1999) for discussion. (iii). All the examples in the main text pertain to the first type.
i. ¿A quién lo premiaron esta vez? ¿A Cosmo o a Jorge?
A who ACC.3SG.MASC rewarded this time A Cosmo or A Jorge
'Who was rewarded this time? Cosmo or Jorge?'
ii. ¿A quién no lo asaltaron alguna vez?
A who not ACC.3SG.MASC robbed some time
'Who wasn't robbed some time?'
iii. ¿A quién lo vio quien?
A who ACC.3SG.MASC saw who
Lit. 'Whom did who see?'

${ }^{6}$ The unacceptability of (19d) does not consider leismo, a dialectal phenomenon in which accusative arguments

${ }^{7}$ Di Tullio and Zdrojewski (2006) observe that clitic doubling with accusative wh-phrases seems to be facilitated in a number of contexts: usually, the doubling pattern suggests a contrastive reading with respect to a set of salient alternatives, e.g., (i); but it can also appear in rhetorical questions, e.g., (ii), and in multiple wh-questions, e.g., 
(21)

$$
\begin{aligned}
& \text { ¿[DOA quién }]_{A C C} \text { lo }{ }_{\{A C C\rangle} \quad \text { viste hoy? } \\
& \text { A who ACC.3SG.MASC saw today }
\end{aligned}
$$

'Who did you see today?'

$$
\begin{gathered}
\text { ¿[IO A quién }]_{D A T} l e_{(D A T)} \quad \text { diste un regalo? } \\
\text { A who DAT.3SG gave a present } \\
\text { 'Who did you give a present to?' }
\end{gathered}
$$

This behaviour extends to free relatives: the wh-phrase heading a free relative may be doubled by a clitic within the embedded clause. As before, the doubling pattern with direct objects in (23) is mostly restricted to certain dialects, while the one with indirect objects should be acceptable for all Spanish varieties.

$$
\begin{aligned}
& \text { Conozco }\left[{ }_{R E L}\left[\begin{array}{lll}
D O & \text { a } & \text { quienes }
\end{array}\right]_{A C C} \quad \operatorname{los}_{(A C C)} \quad \text { premiaron }\right] \text {. } \\
& \text { Know A who ACC.3PL.MASC rewarded }
\end{aligned}
$$

(24) Saludé $\left[_{R E L}[\text { Io a quienes }]_{D A T}\right.$ les ${ }_{(D A T)}$ dieron el premio $]$. greeted A who DAT.3PL gave the prize 'I greeted whom they gave the prize to'

At the same time, the whole relative clause might be dislocated and doubled by a clitic in the matrix clause. As the wh-phrase heads the free relative, the clitic in the matrix structure is expected to match its features. Thus, (25) exhibits a free relative clause functioning as the direct object of the matrix verb salude' 'greeted' in the left periphery of the sentence while being doubled by the matrix accusative clitic lo. Once again, this pattern is restricted to those varieties allowing clitic doubling with accusative whphrases.

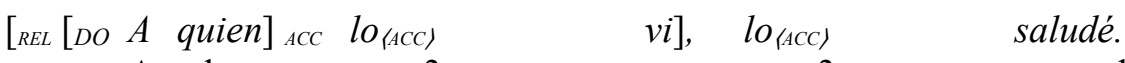

$$
\begin{aligned}
& \text { A who ACC.3SG.MASC saw ACC.3SG.MASC greeted }
\end{aligned}
$$

'Whoever I saw, I greeted.'

Most Spanish speakers are able to replicate this syntactic configuration with a free relative functioning as an indirect object, as in (26). In this sentence, the free relative appearing at the left of the sentence is doubled in the matrix clause by the dative clitic $s e .^{8}$

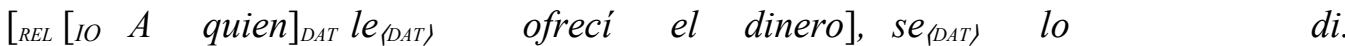

$$
\begin{aligned}
& \text { A who DAT.3SG offered the money DAT.3SG ACC.3SG.MASC gave }
\end{aligned}
$$

'Whoever I offered the money to, I gave it to.'

Importantly, doubling the dislocated free relative in these scenarios is not only possible, but mandatory, e.g., (27) and (28). ${ }^{9}$ This shows that there is a grammatical dependency between the dislocated clause and the matrix clitic that must be respected in order to obtain an acceptable sentence.

\footnotetext{
${ }^{8}$ There is no need to dislocate a dative constituent in order to obtain clitic doubling; the clitics le and les must coappear with dative nominal phrases.

i. Jorge *(le) compró una ensalada a Eliana. Jorge DAT.3SG bought a salad A Eliana

'Jorge bought Eliana a salad.'

However, since wh-phrases are dislocated within free relatives, CLLD constructions are used in all relevant examples in order to homogenize the doubling patterns.

${ }^{9}$ The sentence in (27) is acceptable only with a focal interpretation on the free relative. Such a reading suggests a reanalysis in terms of focus fronting, which is not the aimed-at structure in this example.
} 
(27)

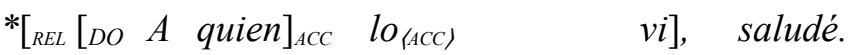

$$
\begin{aligned}
& \text { A who ACC.3SG.MASC saw greeted }
\end{aligned}
$$

'Whoever I saw, I greeted.'

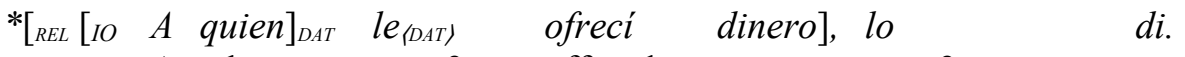

$$
\begin{aligned}
& \text { A who DAT.3SG offered money ACC.3SG.MASC gave }
\end{aligned}
$$

The syntactic configuration in (25) and (26) allows for a case mismatch between accusative and dative clitics. That is, the wh-phrase heading the free relative may be linked at the same time with an accusative clitic within the embedded clause and with a dative clitic at the matrix level, e.g., (29). As already mentioned, clitic doubling of an accusative wh-phrase (e.g., a quien lo insulté) is allowed only in certain dialects, so this pattern is not common to all Spanish varieties.

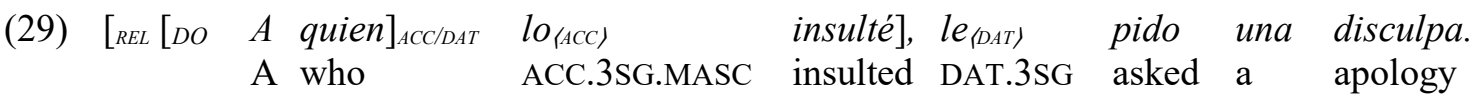

'Whoever I insulted, I asked them for forgiveness.'

The accusative-dative mismatch can also be detected without employing data from dialects that allow doubling of accusative wh-phrases. In a sentence like (30), it could be argued that a verb like insulté 'insulted' selects an accusative complement a quien 'whom' which is supposed to match the matrix dative clitic.

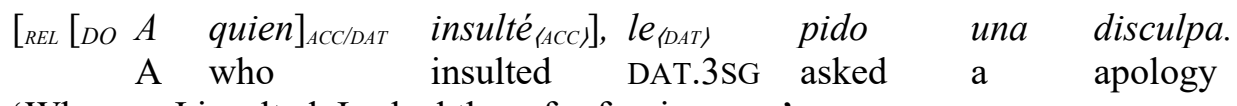

'Whoever I insulted, I asked them for forgiveness.'

The inverse pattern, i.e., the one involving dative clitic doubling within the free relative, is acceptable for speakers of all Spanish varieties. In a sentence like (31), for instance, the wh-phrase a quienes 'whom' is linked with both a dative clitic in the embedded clause and an accusative clitic in the matrix structure.

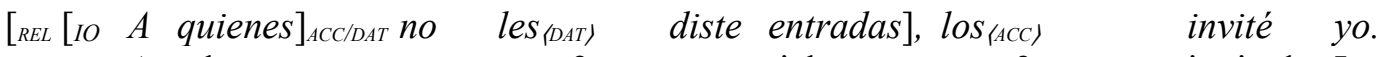

$$
\begin{aligned}
& \text { A who not DAT.3PL gave tickets ACC.3PL.MASC invited I } \\
& \text { 'Whoever you didn't give tickets to, I invited.' }
\end{aligned}
$$

There are two aspects of these examples that are worth noticing. First, CLLD constructions allow the creation of case mismatch scenarios in Spanish, a language that does not exhibit inflectional case. Second, this mismatch leads to acceptable sentences, despite the fact CLLD is subject to a rather strict connectivity requirement, e.g., (19) and (20).

In principle, there are two ways in which this violation of connectivity could be handled. The first one is just accepting that connectivity requirements on CLLD can be lifted in particular contexts; under this approach, the sentences in (29), (30) and (31) should be considered exceptions that need to be accounted for by a proper analysis of CLLD. The second option involves following Zdrojewski (2013), Bárány (2018), and others in assuming that the $a$-forms heading the wh-phrases of (29), (30) and (31) are syncretic and, therefore, allow the repair of the accusative-dative mismatch just as was seen in the German and Polish examples in (12) and (16), respectively. The advantages of this latter alternative are straightforward: (i) it offers an account of the mismatch in terms of a well-known generalization on syncretism, and (ii) it allows the preservation of the rigidness of the connectivity requirements on CLLD. ${ }^{10}$

\footnotetext{
${ }^{10}$ In principle, there is a third possibility: considering that DOM arguments are datives, which is roughly the proposal in Manzini and Franco (2016). According to these authors, DOM arguments and indirect objects are both generated as sisters of a preposition $\mathrm{P}(\subseteq)$, which is spelled out as /a/ in Spanish; thus, DOM and dative are not merely (morphologically) syncretic on this proposal but syntactically identical. The immediate problem with this
} 
Moreover, the configuration introduced in (29), (30) and (31) allows to discriminate between accidental homophony and systematic syncretism. As mentioned in the introduction, the $a$-form in sentences like (32) is considered a directional preposition that is merely a homophone of the DOM and dative markers, i.e., the preposition and the case markers are objects of the Spanish grammar whose exponence is not related through synchronic principles.

(32) Cosmo fue $\left[\begin{array}{lllll}P P & a & \text { la ciudad de } & \text { Nueva York }\end{array}\right]$
Cosmo went
'Cosmo went to the city of New York.'

This distinction makes a clear prediction with respect to selectional mismatches in free relatives: as only true systematic syncretism grants the repairing effect, a mismatch between a dative marker and a preposition should invariably lead to unacceptability. To construct the relevant example, consider the functioning of transfer predicates like enviar 'send' in (33). At least since Masullo (1992), it is widely accepted that there is a correlation between clitic doubling and the category of the argument interpreted as the recipient: if there is no doubling, the constituent is a PP, e.g., (33a); if there is doubling, the constituent is an NP marked as dative, e.g., (33b).
(33) a. El estado francés envió una estatua $\left[\begin{array}{l}P P \\ \text { a }\end{array}\right.$ la ciudad de Nueva York]. The state French sent a statue A the city of New York 'The French State sent a statue to the city of New York.'

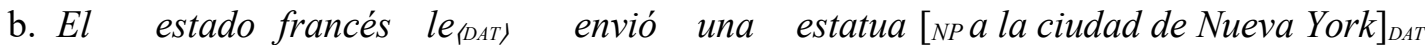 The state French DAT.3SG sent a statue A the city of New York 'The French State sent a statue to the City of New York.'

If the sentences in (32) and (33a) are combined into one by using a free relative structure headed by an $a$-form, the result is acceptable: as the representation in (34) shows, both the matrix and the embedded verbs require a PP.

approach is that it requires rejecting the traditional observation that CLLD is subject to case connectivity. Manzini and Franco predict that accusative clitic doubling with DOM involves a case mismatch, in violation of the connectivity pattern exemplified in (19a).
(i) $\quad\left[\begin{array}{llll}D O & A & C O S m o\end{array}\right]_{D A T}, \quad l o(A C C)$
'Cosmo, I saw him today.' A Cosmo ACC.3SG.MASC saw
vi hoy. where DAT $=\mathrm{PP}(\subseteq)$

Manzini and Franco (2016, p.236) dismiss a similar counterexample by stating that "mismatch in case between members of a chain is independently attested in natural languages" and that "there are no grounds in the theory [of Agree] for the conclusion that all members of a chain must agree (be non-distinct) in case". This posture raises conceptual and empirical issues. First, if case matching is not necessary even for the simplest cases, it is unclear how this framework would deal with more complex examples as those in (29), (30) and (31). Second, if case connectivity is relaxed in the way (i) requires, contrasts involving accusative-dative mismatches in CLLD are left unexplained, e.g., the Greek pair in (ii) and (iii).
(ii) Ton Kósta ton agapá $i$ Maria
the Kostas.ACC CL.ACC loves the Maria.NOM
'Maria loves Kostas.'
(iii). *Tu Kósta ton agapá $i$ Maria the Kostas.DAT CL.ACC loves the Maria.NOM 'Maria loves Kostas.'




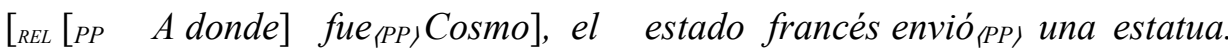 \\ A where went Cosmo the state French sent a statue \\ 'The French State sent a statue where(ever) Cosmo went.'}

However, the sentences in (32) and (33b) cannot be combined in the same way, as (35) shows. ${ }^{11}$ This is because the matrix clitic le requires a dative NP, while the embedded verb fue 'went' requires a PP. There is, therefore, a categorial mismatch. Crucially, since the preposition $a$ and the case marker $a$ are not syncretic, the mismatch cannot be repaired. ${ }^{12}$

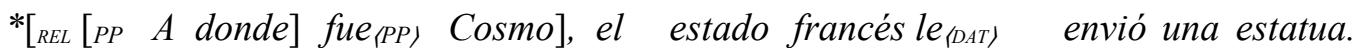

$$
\begin{aligned}
& \text { A where went Cosmo the state French DAT.3SG sent a statue } \\
& \text { 'The French State sent a statue where(ever) Cosmo went.' }
\end{aligned}
$$

In sum, the examples discussed throughout this section show that (i) the Spanish grammar recognizes that the preposition $a$ and the case-marking $a$-forms are underlyingly distinct syntactic objects, no matter that their exponents coincide, while (ii) the $a$-forms corresponding to DOM and dative are equivalent for the purposes of clitic doubling in contexts of free relatives. The next section sketches an analysis of the latter phenomenon.

\section{Dealing with syncretism}

The sketchy analysis in this section follows Zdrojewski's (2013) and Bárány's (2018) treatments of DOM-dative syncretism. The key idea that will be exploited to explain its repairing effect in sentences like (29), (30) and (31) is that case values as accusative or dative are not linguistic primitives, but can be decomposed upon minimal features (e.g., Halle, 1997; McFadden, 2004). The featural composition that will be assumed for accusative and dative is taken from McFadden (2004). ${ }^{13}$

(36) a. Accusative $=\{[\mathrm{CASE}]$, [INFERIOR $]\}$

b. Dative $=\{[\mathrm{CASE}],[$ INFERIOR $],[\mathrm{OBLIQUE}]\}$

If the featural content of accusative and dative case-marking goes according to (36), the connectivity requirements on CLLD must make reference to these primitives and not to their convenient "labels" accusative and dative. Under this assumption, the case mismatches in the examples in (29), (30) and (31) simply disappear, as accusative and dative are no longer absolutely distinct values, but are composed by some overlapping features.

Take the sentence in (29). As shown in (37a), both the matrix and embedded clitics find features matching their own in the wh-phrase, i.e., the dative clitic le manages to match its [CASE], [INFERIOR] and [OBLIQUE] features with those in the wh-phrase, while the accusative clitic lo matches its [CASE] and [INFERIOR] features. Basically the same happens with respect to the sentence in (30), as sketched in (37b); there is only one difference: in this case, it is the embedded verb insulté 'insulted' that requires an accusative complement, i.e., an element carrying [CASE] and [INFERIOR] features, a need that can be satisfied by the wh-phrase. Finally, the sentence in (31), as sketched in (37c), replicates the same matching pattern with the clitics in inverted positions, i.e., the dative appears within the embedded clause while the accusative is at the matrix level. ${ }^{14}$

\footnotetext{
11 Notice that the sentence in (35) is acceptable under the interpretation that the recipient of the statue is Cosmo himself, and not the place where he is at.

${ }^{12}$ The argument may also be posited in the following way. The embedded verb fue 'went' requires the sequence $a$ donde to consist of a preposition and a locative, while the matrix clitic le requires it to consist of a dative case marker and a locative. Crucially, the latter is an ungrammatical sequence in Spanish, which is why (35) is unacceptable. Thus, it may be concluded the grammar distinguishes both $a$-forms, despite the fact they are pronounced in the same way, i.e., they function as mere homophones.

${ }^{13}$ According to McFadden (2004), the feature [CASE] allows signalling that an element is case-marked. Therefore, it is part of every case value.

${ }^{14}$ A potential drawback of this analysis is that it seemingly predicts the grammaticality of cases as (20c), i.e., since the features of the accusative clitic la ([CASE] and [INFERIOR]) match those in the dislocated indirect object a Eliana ([CASE], [INFERIOR], and [OBLIQUE]), this sentence would be wrongly expected to be acceptable. However, this
} 
(37) a. [ReL wh-phrase $\left\{\left[\right.\right.$ CASE], [inf.], [OBL.]\} $\left.\ldots \mathrm{lo}_{\langle[\mathrm{CASE}],[\mathrm{INF} .]\rangle}\right] \ldots \mathrm{le}_{\langle[\mathrm{CASE}],[\mathrm{INF} .],[\mathrm{OBL} .]\rangle}$

b. $\left[\right.$ ReL wh-phrase $\left\{[\mathrm{CASE}],\left[\right.\right.$ [NF.], [OBL.]\} $\left.\ldots \mathrm{V}_{\langle[\mathrm{CASE}],[\mathrm{INF} .]\rangle}\right] \ldots \mathrm{le}_{\langle[\mathrm{CASE}],[\mathrm{INF} .],[\mathrm{OBL} .]\rangle}$

c. $\left[\right.$ ReL wh-phrase $\left\{[\mathrm{CASE}],\left[\right.\right.$ [NF.], [OBL.]\} $\ldots \mathrm{le}_{\langle[\mathrm{CASE}],[\mathrm{INF} .],[\mathrm{OBL} .]\rangle]} \ldots \mathrm{lo}_{\langle[\mathrm{CASE}],[\mathrm{INF} .]\rangle}$

By adopting the feature composition of accusative and dative in (36), the syncretism phenomenon can be captured by employing a single spell-out rule. The intuition is that the exponent /a/ realizes the combination of the features [CASE] and [INFERIOR], so it corresponds to both accusative and dative cases.

$$
\begin{aligned}
& \text { Spell-out rule } \\
& \{[\text { CASE }],[\text { INFERIOR] }\} \rightarrow / a /
\end{aligned}
$$

If /a/ is the exponent corresponding to accusative case in Spanish, it remains to be explained why inanimate direct objects do not receive this mark, e.g., (39).

\begin{tabular}{|c|c|}
\hline $\begin{array}{l}\text { Cosmo } \\
\text { Cosmo }\end{array}$ & $\begin{array}{l}\text { vio } \quad[D O \\
\text { saw }\end{array}$ \\
\hline
\end{tabular}

'Cosmo saw the movie.'

Following López (2012), it is assumed that direct objects without DOM are licensed through incorporation into the verb, while only those direct objects headed by an $a$-form truly receive accusative case.

\section{Conclusion}

In Spanish, the form /a/ can be taken to function as a DOM marker, a dative marker, or a directional preposition. While it could be possible that this homophony is (synchronically) accidental, this could also be a case of systematic syncretism, i.e., principles of the Spanish grammar enforce the employment of the same form for different grammatical values.

This paper has suggested that the repairing effect that syncretism exhibits with respect to feature mismatches in free relatives can be used as a diagnosis to settle the issue. Indeed, by combining CLLD and free relative constructions, it is attested that the mismatch between DOM and dative still produces grammatical sentences. This shows that DOM and dative are syncretic categories in Spanish. On the contrary, the preposition $a$ does not repair mismatches, so it must be considered a mere homophone of the $a$-forms that mark case.

\section{Acknowledgments}

I wish to thank Pablo Zdrojewski and two anonymous reviewers for their valuable comments and suggestions. I am also grateful to audiences at NELLi Away Day (Newcastle University) and III Congreso de la Delegación Argentina de ALFAL (National University of La Plata) for discussion on previous versions of this paper. Usual disclaimers apply.

\section{References}

Alarcos Llorach, E., 1994. Gramática de la lengua española. Madrid: Espasa Calpe.

Alcina Franch, J. and Blecua, J., 1975. Gramática española. Barcelona: Ariel.

Bárány, A., 2018. DOM and dative case. Glossa: a Journal of General Linguistics, vol. 3, pp. 140.

Bergsma, F., 2019. Mismatches in free relatives - grafting nanosyntactic trees. Glossa: a Journal of General Linguistics, vol. 4, pp. 1-37.

Blake, B., 1994. Case. Cambridge: Cambridge University Press.

Brugè, L. and Brugger, G., 1996. On the accusative $a$ in Spanish. Probus, vol. 8, no. 1, pp. 1-52.

problem can be elegantly avoided by noticing that the features of the clitic must also satisfy the selectional requirements of its verb (i.e., the verb needs to match the features of both its NP argument and the clitic). Concretely, the verb $d i$ 'gave' in (20c) requires a dative clitic with [CASE], [INFERIOR], and [OBLIQUE] features. 
Cinque, G., 1977. The movement nature of left dislocation. Linguistic Inquiry, vol. 8, no. 2, pp. $397-412$.

Citko, B., 2013. Size matters: Multidominance and DP structure in Polish. Paper presented at the 44th Poznan Linguistic Meeting. Adam Mickiewicz University.

Cuervo, C., 2003. Datives at large. Cambridge, MA: MIT dissertation.

Demonte, V., 1995. Dative alternation in Spanish. Probus, vol. 7, no. 1, pp. 5-30.

Di Tullio, Á. and Zdrojewski, P., 2006. Notas sobre el doblado de clíticos en el español rioplatense: asimetrías entre objetos humanos y no humanos. Filología, vol, 37, pp. 13-44.

Dobrovie-Sorin, C., 1990. Clitic Doubling, Wh-Movement and Quantification in Romanian. Linguistic Inquiry, vol. 21, no. 3, pp. 351-397.

Fernández-Ordóñez, I., 1999. Leísmo, laísmo y loísmo. In: I. Bosque and V. Demonte, eds. Gramática descriptiva de la lengua española. Volumen I: Sintaxis básica de las clases de palabras. Madrid: Espasa Calpe, pp. 1317-1397.

Halle, M., 1997. Distributed morphology: Impoverishment and fission. MIT Working Papers in Linguistics (MITWPL), vol. 30, pp. 425-449.

Himmelreich, A., 2017. Case matching effects in free relatives and parasitic gaps. Leipzig: Universität Leipzig dissertation.

Jaeggli, O., 1982. Topics in Romance syntax. Dordrecht: Foris.

López, L., 2012. Indefinite objects: Scrambling, choice functions, and differential marking. Cambridge, MA: MIT Press.

Manzini, R. and Franco, L., 2016. Goal and DOM datives. Natural Language and Linguistic Theory, vol. 34, pp. 197-240.

Masullo, P., 1992. Incorporation and the case theory in Spanish. Seattle: University of Washington dissertation.

McFadden, T., 2004. The position of morphological case in the derivation: a study on the syntaxmorphology interface. Philadelphia: University of Pennsylvania dissertation.

Ordóñez, F., 2012. Clitics in Spanish. In: I. Hualde, A. Olarrea and E. O'Rourke, eds. The handbook of Hispanic linguistics. Malden: Wiley-Blackwell, pp. 423-451.

Pensado, C., 1995. El complemento directo preposicional. Madrid: Visor.

Pujalte, M., 2012. Argumentos (no) agregados. Indagaciones sobre la morfosintaxis de la introducción de argumentos en español. Buenos Aires: Universidad de Buenos Aires dissertation.

Suñer, M., 1984. Free relatives and the matching parameter. The Linguistic Review, vol. 3, no. 4, pp. 363-387.

Suñer, M., 1988. The role of agreement in clitic-doubled constructions. Natural Language and Linguistic Theory, vol. 6, pp. 391-434.

Torrego, E., 1999. El complemento directo preposicional. In: I. Bosque and V. Demonte, eds. Gramática descriptiva de la lengua española. Volumen 2: Las construcciones sintácticas fundamentales. Relaciones temporales, aspectuales y modales. Madrid: Espasa Calpe, pp. $1780-1805$.

van Riemsdijk, H., 2006. Free relatives. In: M. Everaert and H. van Riemsdijk, eds. The Blackwell companion to syntax. Oxford: Blackwell Publishing, pp. 338-382.

Vogel, R., 2001. Case conflict in German free-relative constructions. an optimality-theoretic treatment. In: G. Müller and W. Sternefeld, eds. Competition in syntax. Berlin: Mouton de Gruyter, pp. 341-375.

Zdrojewski, P., 2013. Spanish DOM as a case of lacking Case. Paper presented at the Differential Object Marking Workshop. University of Tromsø. 